\title{
PENGUATAN PENDIDIKAN KARAKTER MELALUI KEARIFAN LOKAL BERBASIS AL-QUR'AN (IMPLEMENTASI DI SMAN KABUPATEN PURWAKARTA)
}

\author{
Darwis Hude ${ }^{1}$, Nur Arfiyah Febrianti ${ }^{2}$, Cece $^{2}$ \\ Institut PTIQ Jakarta, Institut PTIQ Jakarta, Mahasiswa \\ Pascasarjana Institut PTIQ Jakarta \\ Email :darwishude@yahoo.co.id,febriani@ptiq.ac.id. \\ cecenurhikmah01@gmail.com
}

\begin{abstract}
ABSTRAK
Disertasi ini membahas mengenai penguatan pendidikan karakter melalui kearifan lokal berbasis Al-Qur'an yang dipahami dalam arti adat istiadat atau kebiasaan yang merupakan warisan budaya nenek moyang secara turun temurun dari generasi ke generasi yang dilestarikan keberadaannya sejauh tidak menyalahi nilai-nilai yang terdapat di dalam Al-Qur'an.

Disertasi ini menemukan bahwa penguatan pendidikan karakter melalui kearifan lokal berbasis Al-Qur'an yang di implementasikan di SMAN Kabupaten Purwakarta, terjadi penguatan yang signifikan. Penguatan tersebut yaitu implementasi Perbup Nomor 69 Tahun 2015 tentang 7 Poe Atikan Istimewa yang meliputi Senen "Ajeg Nusantara" (Tegak di wilayah Negara Kesatuan Republik Indonesia), Salasa "Mapag di Buana" (Menjemput Dunia), Rebo "Maneuh di Sunda" (Diam/Tinggal dengan Adat Budaya Sundanya), Kemis "Nyanding Wawangi" (Menyukai Estetika Berbudaya serta Memiliki Jiwa Seni yang bisa Membawa Harum Tanah Air), Juma'ah "Nyucikeun Diri" (Mensucikan Diri), dan SabtuMinggu "Betah di Imah" (Nyaman Tinggal bersama Keluarga di Rumah). Penguatan karakternya yang terjadi adalah karakter yang bersifat agamis, ukhrowi, nasionalis, tauhid, nilai ritualitas dan spiritualitas, dan akhlak.
\end{abstract}

Kata Kunci : Penguatan, Pendidikan Karakter, Al-Qur'an 


\begin{abstract}
This dissertation discusses the strengthening of character education through local wisdom based on Al-Qur'an which is understood in the sense of customs or habitual which are the ancestral cultural heritage from generation to generation which has been preserved as long as they do not violate the values contained in the Al-Qur'an.

This dissertation found that strengthening character education through local wisdom based on Al-Qur'an which is implemented at Purwakarta senior high school, had a significant strengthening. The reinforcement is the implementation of regent regulation number 69 of 2015 concerning "7 Poe Atikan Istimewa" which cover, Senen "Ajeg Nusantara" (Upright in the territory of the Republic of Indonesia), Salasa "Mapag di Buana" (Pick up the world), Rebo "Maneh di Sunda" (Silence / Stay with the Sundanese Cultural Customs), Kemis "Nyanding Wawangi" (Loves Cultured Aesthetics and Has a Soul of Art that Can Bring Fragrant Motherland), Juma'ah "Nyucikeun Diri" (Purify our selves), Sabtu-Minggu "Betah di Imah" (Comfortable Living with Family at Home). The character reinforcement that occurs is a religious character, ukhrowi, nationalist, monotheism, spiritual values and spirituality, and morals.
\end{abstract}

Keywords : Strength, Character Education, Al-Qur'an 


\section{A. PENDAhULUAN}

Pendidikan adalah upaya sadar manusia dalam memahami diri sendiri dan lingkungannya atau upaya manusia dalam memahami interaksi antara makro dan mikro kosmosnya. Oleh sebab itu pendidikan harus mampu memupuk dan menumbuhkan kesadaran akan arti keberadaan manusia pada lingkungan serta alam sekitarnya.

Pengaruh globalisasi ini tak luput menjadi perhatian dalam dunia pendidikan, salah satunya penggunaan media elektronik seperti gadget marak di kalangan pelajar yang seutuhnya tidak selalu berdampak positif, namun ada sisi negatifnya yang menjadikan dirinya tidak lagi mengenal budaya sendiri tapi lebih banyak mengenal budaya luar. Padahal, salah satu yang perlu mendapat perhatian pada era globalisasi ini adalah 'identitas kebangsaan'. Hal ini tentu salah satu faktor penyebabnya adalah kurangnya dukungan dari keluarga, karena akhir-akhir ini lingkungan keluarga pada sebagian kecil masyarakat kita relatif sudah tidak mengajarkan lagi nilai-nilai budaya lokal padahal lingkungan keluarga menjadi faktor utama dalam pembentukan karakter siswa yang mampu memberi makna bagi kehidupannya di masa depan. Contoh, penggunaan bahasa daerah (sunda) dalam keseharian di lingkungan keluarga sudah berkurang, akibatnya pemahaman siswa-siswi pada mata pelajaran ini pun akhirnya menjadi minim, padahal asal orang tua juga keturunan keluarganya adalah asli Suku Sunda -inilah salah satu dampak dari globalisasi-. Untuk itu, pengaruh lingkungan sekitar dan lingkungan keluarga memiliki kontribusi yang sangat besar dalam pembentukan manusia yang berintegritas tinggi, berkarakter sehingga melahirkan generasi penerus bangsa yang hebat dan bermartabat sesuai dengan spirit pendidikan yaitu "memanusiakan manusia".

Derasnya globalisasi ini sangat dikhawatirkan dapat mengakibatkan terkikisnya kecintaan generasi muda pada bangsa dan negara yang kian hari kian memudar dan menjadikan mereka tidak lagi bangga dengan budaya daerahnya (budaya lokal). Oleh karena itu penanaman budaya lokal sangat penting diberikan kepada peserta didik selain dapat juga membantu untuk menanamkan rasa nasionalismenya. Karena itu akan lebih baik jika diupayakan bagaimana cara aneka ragam budaya yang telah kita miliki tersebut bisa dipelajari kembali, dijaga dan dilestarikan secara bersama-sama. 
Maka tak heran, jika globalisasi dianggap sebagai dewa penolong ketika kearifan lokal (local wisdom) tak mampu mengubah mindset dan horizon harapan bangsa ini. Sehingga ketika memasuki millenium kedua ini, bangsa kita masih saja pada posisi euphoria globalisasi. Dimana segalanya ingin diperoleh secara praktis dan instan, sehingga menafikan nilai kerja keras, kerjasama dan kejujuran dalam berkarya. Siapa lagi yang bisa menolong kita dari perangkap globalisasi? Ternyata globalisasi diam-diam membius nilai kebangsaan kita. Maka melalui pendidikan local wisdom (kearifan lokal) inilah diharapkan tercipta pendidikan yang mampu memberi makna bagi kehidupan manusia. Artinya pendidikan mampu menjadi spirit yang mewarnai dinamika manusia Indonesia ke depan.

Berbicara pendidikan karakter melalui kearifan lokal ini sebenarnya adalah bentuk refleksi dan realisasi dari Peraturan Pemerintah (PP) Nomor 19/2005 tentang Standar Nasional Pendidikan, yaitu pasal 17 ayat 1 yang menjelaskan bahwa "kurikilum tingkat satuan pendidikan SD-SMA, atau bentuk lain yang sederajat dikembangkan sesuai dengan satuan pendidikan, potensi daerah, sosial budaya, dan peserta didik". Sebaliknya, pemerintah senantiasa bertindak tegas dalam menghadapi berbagai tafsir keragaman yang berasal dari luar pemerintahan. Termasuk keberadaan nilai-nilai kearifan lokal pun dinafikan demi terselenggaranya pemerintahan yang efektif dan pembangunan nasional. Sebagai konsekuensinya, kesatuan terlihat lebih menonjol, ketimbang persatuan.

Kearifan lokal merupakan produk budaya masa lalu yang patut terus menerus dijadikan pegangan hidup. Meskipun bernilai lokal tetapi nilai yang terkadung didalamnya sangat universal. Hal ini dikuatkan dengan pernyataan Tukijo yaitu "Bangsa ini kaya dengan nilai lokal yang bersumber dari tata adat istiadat, budaya, tradisi yang terinternalisasikan dalam perilaku masyarakat suatu suku atau daerah". ${ }^{1}$ Dengan demikian, nilainilai budaya lokal yang bersumber dari tata adat istiadat, budaya serta tradisi akan menjadi karakter dari sebuah generasi dalam masyarakat tersebut, karenanya betapa penting budaya lokal dalam perilaku masyarakat ini, baik karakter bersifat individual maupun karakter bangsa. Bisa pula diistilahkan knowledge is power, but character is more (pengetahuan adalah kekuatan tapi

1 Tim Kreatif LKM, Restorasi Pendidikan Indonesia Menuju Masyarakat Terdidik Berbasis Budaya, Jakarta: Ar-Ruzz Media, 2011, hal. 146. 
watak memiliki nilai dari pada itu). Maka dari itu, sebenarnya pembangunan karakter penting untuk mencapai tujuan hidup manusia pada umumnya. Hal senada tentang kearifan lokal ini dikemukakan Gertz, dalam bukunya Kebudayaan dan Agama, "Kearifan lokal merupakan norma yang berlaku dalam suatu masyarakat yang diyakini kebenarannya dan menjadi acuan dalam bertindak dan berperilaku sehari-hari, seperti dalam pendidikan agama". ${ }^{2}$

Untuk menguatkan tupoksi guru berkaitan dengan penanaman kearifan lokal tersebut, Haryati Sobadio mengatakan Local Genius adalah identitas/kepribadian bangsa yang menyebabkan bangsa tersebut mampu menyerap dan mengolah kebudayaan asing sesuai dengan watak dan kemampuan sendiri. Moendarjito menambahkan bahwa unsur budaya daerahlah sebagai lokal genius yang telah teruji kemampuannya untuk bertahan sampai sekarang. Adapun ciri-ciri dari Lokal Genius ini diantaranya: (1) Mampu bertahan terhadap budaya luar; (2) Memiliki kemampuan mengakomodasi unsur-unsur budaya luar; (3) Mempunyai kemampuan mengintegrasikan unsur budaya luar ke dalam budaya asli; (4) Mempunyai kemampuan untuk mengendalikan; dan (5) Mampu memberi arah pada perkembangan budaya. Jika demikian maka dapat dipastikan guru dapat diharapkan mengupayakan apa yang diharapkan semua peserta didik sehingga keberhasilannya tanpa memandang latar belakang mereka serta dapat diharapkan akan terjadi peningkatkan kemampuan teknis guru yang lebih kompeten. ${ }^{3}$

Revitalisasi kearifan lokal dalam pendidikan ini sebagai upaya pemerintah daerah memberikan sumbangan penting dalam mencapai tujuan pendidikan. ${ }^{4}$ Diharapkan melalui sistem pendidikan yang menonjolkan kearifan lokal pada timgkat SMA di Kabupaten Purwakarta ini dapat menghasilkan kualitas peserta didik yang cerdas, berakhlak mulia (berkarakter baik) dan beradab dengan menghargai budaya sundanya. Dengan demikian dapat memposisikan subjek didik sebagai pribadi dan anggota masyarakat yang memiliki kebiasaan efektif (pengetahuan,

${ }^{2}$ Clifford Gertz, Kebudayaan dan Agama, Jakarta: Rajawali Pers, 2010, hal. 112.

3 Al-Jufri B.Syarif dkk., Reorientasi Ilmu Pendidikan di Indonesia, Jakarta: Educatio, IKIP Muhammadiyah Jakarta Press, 1995, hal. 116.

${ }^{4}$ Lihat pada Bab-3 "Prinsip Pembangunan Karakter" dalam Kang Dedi Menyapa: Kumpulan Pemikiran, Jakarta: Media Indonesia Publishing, 2013, hal. 42-49. 
keterampilan dan keinginan) secara harmonis dengan meninggalkan ketergantungan (dependence) menuju kemandirian (independence) dan kesalingtergantungan (interdependence). Untuk itu diperlukan keterampilan membangun hubungan serasi dalam lingkungan sosial yang berkarakter, saling mempengaruhi (baik dalam keluarga, sekolah, dan masyarakat) karena pendidikan kearifan lokal ini adalah hal vital untuk dilakukan menuju perubahan bagi masyarakat purwakarta.

Munculnya fenomena adanya suatu sistem pendidikan yang menghargai bangsa dan budayanya (pendidikan nilai/karakter) dengan menggali nilai-nilai lokal sebagai landasan nilai kehidupan daerah yang terinternalisasi dalam dunia pendidikan ini, diharapkan mampu mengembangkan pribadi peserta didik memiliki karakter bangsa dan budaya yang kompeten dan bermartabat. Untuk itulah perlu adanya dukungan masyarakat untuk pembaharuan dalam sistem pendidikan agar lebih berkarakter, cerdas dan berakhlak mulia.

Dari uraian di atas, jelaslah bahwa untuk melahirkan peserta didik yang berkarakter maka perlu pendidikan yang mengedepankan karakter bangsa dan budayanya di sekolah, hal ini merupakan kebutuhan yang tidak terhindarkan agar generasi penerus dapat dibekali dengan kemampuan-kemampuan dasar yang menjadikannya life-long learners (pembelajar sepanjang hayat) sebagai salah satu karakter penting hidup di era informasi yang bersifat global, serta mampu berfungsi dengan peran positif sebagai pribadi, anggota keluarga, warga negara, maupun warga dunia. Untuk itu peneliti mencoba menuangkan permasalah ini dengan judul: Penguatan Pendidikan Karakter Melalui Kearifan Lokal Berbasis Al-Qur'an (Implementasi di SMAN Kabupaten Purwakarta).

\section{B. PENGUATAN PENDIDIKAN KARAKTER MELALUI KEARIFAN LOKAL}

Dalam Bahasa Inggris, character, memiliki arti watak, sifat, peran, karakter, dan huruf. ${ }^{5}$ Karakter bermakna watak adalah sifat lain manusia yang mempengaruhi segenap pikiran dan tingkah laku; budi pekerti, tabiat dasar. ${ }^{6}$ Endang Sumantri menyatakan, karakter ialah suatu kualitas positif yang dimiliki

\footnotetext{
${ }^{5}$ John M.Echols \& Hasan Shadily, Kamus Inggris Indonesia, AN EnglishIndonesia, Jakarta: Gramedia, 2003, hal. 109-110.

${ }^{6}$ Departemen Pendidikan dan Kebudayaan, Kamus Besar Bahasa Indonesia, Jakarta: Balai Pustaka, 2000, hal. 445.
} 
seseorang sehingga membuatnya menarik dan atraktif; reputasi seseorang; seseorang yang unusual atau memiliki kepribadian yang eksentrik. ${ }^{7}$

Pendidikan karakter menurut Thomas Lickona adalah pendidikan untuk membentuk kepribadian seseorang melalui pendidikan budi pekerti, yang hasilnya terlihat dalam tindakan nyata seseorang, yaitu tingkah laku yang baik, jujur bertanggung jawab, menghormati hak orang lain, kerja keras, dan sebagainya. Aristoteles berpendapat bahwa karakter itu erat kaitannya dengan kebiasaan yang kerap dimanifestasikan dalam tingkah laku. Definisi pendidikan karakter selanjutnya dikemukakan oleh Elkind \& Sweet.

Sesungguhnya, hakikat dari pendidikan karakter sendiri berpijak dari karakter dasar manusia yang bersumber dari nilai moral universal (bersifat absolut) dan bersumber dari agama yang juga disebut sebagai the golden rule. Pendidikan karakter dapat memiliki tujuan yang pasti apabila berpijak dari nilai-nilai karakter dasar tersebut. Menurut para ahli psikologi, beberapa nilai karakter dasar tersebut adalah: cinta kepada Allah dan ciptaan-Nya (alam dengan isinya), tanggung jawab, jujur, hormat, dan santun, kasih sayang, peduli dan kerjasama, percaya diri, kreatif, kerja keras, dan pantang menyerah, keadilan dan kepemimpinan; baik dan rendah hati, toleransi, cinta damai, dan cinta persatuan. Pendapat lain menyatakan bahwa karakter dasar manusia terdiri dari: dapat dipercaya, rasa hormat dan perhatian, peduli, jujur, tanggung jawab, kewarganegaraan, ketulusan, berani, tekun, disiplin, visioner, adil, dan punya integritas. ${ }^{8}$

Berdasarkan uraian di atas dapat dipahami bahwa pendidikan karakter memiliki landasan filosfis dan normatif sebagai pijakan dalam operasionalnya. Hal ini mengingat bahwa karakter merupakan pengetahuan yang memikirkan hakikat kehidupan manusia dalam bertingkah laku sehingga diperlukan landasan sebagai pedoman dalam berinteraksi dan berasosiasi.

Berdasarkan pembahasan tersebut, dapat ditegaskan bahwa pendidikan karakter merupakan upaya-upaya yang dirancang dan dilaksanakan secara sistematis untuk membantu peserta didik memahami nilai-nilai perilaku manusia yang

7 Endang Sumantri, "Pendidikan Karakter sebagai Pendidikan Nilai: Tinjauan Filosofis Agama, dan Budaya", disampaikan pada Seminar Pendidikan Karakter, Jakarta 23 Mei 2009, makalah tidak diterbitkan.

8 John W.Santrock, A Tropical Approach to Life-Span, New York: McGrawHill, 2002, hal. 433. 
berhubungan dengan Tuhan Yang Maha Esa, diri sendiri, sesama manusia, lingkungan dan kebangsaan yang terwujud dalam pikiran, sikap, perasaan, perkataan, dan perbuatan berdasarkan norma-norma agama, hukum, tata krama, budaya dan adat istiadat. Intinya pendidikan karakter adalah upaya yang sistematis untuk menambahkan dan sekaligus mengembangkan secara konsisten dan terus menerus kualitas-kualitas karakter yang berbasis pada nilai agama, budaya dan falsafah negara yang diinternalisasi oleh peserta didik di rumah, di sekolah maupun di masyarakat dalam kehidupan kesehariannya, sehingga akan membentuk perilaku berkarakter.

Adapun Kearifan Lokal dilihat dari kamus InggrisIndonesia, terdiri dari dua kata yaitu kearifan (wisdom) dan lokal (local). Local berarti setempat dan wisdom sama dengan kebijaksanaan. Dengan kata lain maka local wisdom (kearifan setempat) dapat dipahami sebagai gagasan-gagasan, nilai-nilai, pandangan-pandangan setempat (lokal) yang bersifat bijaksana, penuh kearifan, bernilai baik yang tertanam dan diikuti oleh anggota masyarakatnya. ${ }^{9}$ Jelas disini bahwa kearifan lokal itu berkaitan dengan nilai-nilai baik yang merupakan warisan nenek moyang masa lalu dan dijadikan pedoman atau landasan berpijak oleh anggota masyarakat setempat. Untuk itu, kearifan lokal menjadi penting dalam pendidikan karakter. Karena pada dasarnya kearifan lokal merupakan kebenaran yang telah mentradisi atau ajeg dalam suatu daerah.

Kearifan lokal merupakan produk budaya masa lalu yang patut secara terus-menerus dijadikan pegangan hidup, meskipun bernilai lokal tetapi nilai yang terkandung didalamnya sangat universal sehingga dengan mengintegrasikan kearifan lokal dalam desain pembentukan karakter anak, secara tidak langsung anak mendapatkan gambaran yang utuh atas identitas dirinya sebagai individu, serta sebagai anggota masyarakat yang terikat dengan budaya yang unggul. ${ }^{10}$

Selain itu kearifan lokal juga merupakan pengetahuan eksplisit yang muncul dari periode panjang, berevolusi bersamasama masyarakat dan lingkungannya dalam sistem lokal. Proses

${ }^{9}$ Sartini, Menggali Kearifan Lokal Nusantara Sebuah Kajian Filsafati, http://dgi-indonesia.com, diakses pada 30 November 2015.

10 Wagiran, "Pengembangan Model Pendidikan Kearifan Lokal dalam Mendukung Visi Pembangunan Provinsi Daerah Istimewa Yogyakarta 2020, dalam Jurnal Penelitian dan Pengembangan, Vol.III Nomor 3, tahun 2011, hal. 17-21. 
evolusi yang begitu panjang dan melekat dalam masyarakat ini dapat menjadikan kearifan lokal sebagai sumber energi potensial dari sistem pengetahuan kolektif masyarakat untuk hidup bersama secara dinamis dan damai. Karena bangsa Indonesia merupakan bangsa timur yang religi, ${ }^{11}$ maka budaya (kearifan lokal)nya pun bernuansa ketimuran dan agamis.

Bila kita lihat dari pengertiannya, maka kearifan lokal dan keunggulan lokal memiliki hubungan, yaitu kearifan lokal merupakan kebijakan manusia dalam mengembangkan keunggulan lokal yang bersandar pada filosofi nilai-nilai, etika, cara-cara dan perilaku yang melembaga secara tradisional. Dengan demikian pendidikan berbasis kearifan lokal atau keunggulan lokal adalah pendidikan yang memanfaatkan keunggulan lokal dan global dalam aspek ekonomi, seni budaya, SDM, bahasa, teknologi informasi dan komunikasi, ekologi, dan lain-lain ke dalam kurikulum sekolah yang akhirnya bermanfaat bagi pengembangan kompetensi peserta didik yang dapat dimanfaatkan untuk persaingan global.

Jika kearifan lokal ini ditinjau dalam perspektif agama Islam. Secara etimologi ' $U r f$ berarti sesuatu yang dipandang baik, yang dapat diterima akal sehat. Menurut kebanyakan ulama ' $U r f$ dinamakan juga adat, sebab perkara yang telah dikenal itu berulangkali dilakukan manusia. Para ulama ushul fiqh membedakan antara adat dengan ' $U r f$ dalam kedudukannya sebagai dalil untuk menetapkan hukum syara. Sebagaimana dikemukakan oleh Mukhtar Yahya dalam artikelnya tentang Istidlal, menjelaskan adat dan 'Urf. Adat didefinisikan dengan sesuatu yang dilakukan secara berulang-ulang tanpa adanya hubungan rasional.

Dari penjelasan di atas jelas bahwa, dalam bahasa agama kearifan lokal adalah ' $U r f$, berkaitan dengan pewarisan budaya nenek moyang kepada generasi berikutnya yang tergolong baik dan dilanjutkan/ dilestarikan keberadaannya. Dalam hal ini kearifan lokal (' $U r f$ ) menurut ajaran agama terbagi menjadi dua bagian, yakni: al-'urf al-shahih (kebiasaan yang selaras dengan syariat) dan al-'urf al-fasid (kebiasaan yang bertentangan dengan syariat). Al-'urf dalam pengertian al-'urf al-shahih, oleh sebagian

11 Bangsa yang religi disini maksudnya bahwa bangsa Indonesia memiliki sejarah tentang masuknya agama-agama besar pernah berada di negeri ini dan dianut oleh penduduk nusantara contohnya; agama Islam, Agama Kristen (Katholik dan Protestan), agama konghutcu, Hindu dan agama Budha. 
besar ulama dianggap absah sebagai dalil hukum. Oleh karena itu, terdapat kaidah figh asasi yang berbunyi al-'adah almuhakamah. $^{12}$ Jadi yang dikembangkan dalam rangka membentuk karakter peserta didik adalah al-'urf al-shahih (kebiasaan yang selaras dengan syariat). Contohnya tradisi merayakan hari besar keagamaan seperti maulid, Isra mi'raj, halal bihalal, berjabatan tangan (salaman sambil mencium tangan) bila bertemu dengan yang lebih tua dan lain-lain.

Berkaitan dengan pendidikan karakter, pendidikan kearifan lokal yang penulis bahas ini pun sering dianggap sebagai kearifan tradisional dan tradisi. Heddy Shri AhimsaPutra, dalam artikelnya memilih menggunakan kearifan tradisional karena dianggap ada permasalahan konseptual, teoretis, dan implikasi metodologis yang sulit digunakan dalam penelitian. Secara menyeluruh, pengertian kearifan tradisional itu sendiri menurut Ahimsa-Putra adalah perangkat pengetahuan tradisional yang diselesaikan secara bijaksana, baik, dan benar serta diperoleh dari generasi-generasi sebelumnya secara lisan melalui tindakan.

Pola pendidikan karakter berbasis kearifan budaya lokal di sekolah tersebut telah memberikan dampak positif dengan mampu melaksanakan beberapa aspek khususnya pada hal: (a) nilai dasar karakter/budaya daerah yang mampu bertahan dan menjadi budaya sekolah, keluarga dan masyarakat, (b) program kurikuler dan ekstrakurikuler sekolah terintegrasi dan mendukung pendidikan karakter di sekolah, (c) kepala sekolah beserta guru sebagai teladan, pengganti orang tua di sekolah mampu menjadi sebagai pengayom, pengontrol, pengendali terhadap budi pekerti siswa dan pelaksanaan pendidikan karakter di lingkungan sekolah. ${ }^{13}$ Dari penelitian tersebut, tampak bahwa kearifan lokal sangat penting dilaksanakan terutama berkaitan dengan pembentukan karakter siswa.

Pendidikan berkearifan lokal merupakan model pendidikan yang tak begitu menjunjung tinggi formalitas. Ia tidak berwujud konsep-konsep melangit yang sulit terjangkau anak didik. Ia juga bukan materi khusus yang diajarkan kepada anak

12 Abdur Rasyid, "Membahas Dalil-Dalil Hukum". Dalam Hukum Islam Al- 'Uruf http://www.fahmina.or.id. Diakses pada 3 Maret 2016 Jam 21.00.

${ }^{13}$ Yadi Nuryadi, " Model Pendidikan Karakter Berbasis Kearifan Lokal” (Penelitian Tehadap Masyarakat Kampung Benda Kerep Cirebon provinsi Jawa Barat untuk Pengembangan Pendidikan Karakter di Sekolah", http://file.upi.edu. Diakses 25 Mei 2016. 
didik pun, tidak harus dimasukkan ke dalam kurikulum atau silabi pendidikan. Walaupun demikian sebenarnya pendidikan karakter sebagaimana diungkapkan oleh Syarifudin Almadari, dalam bukunya Rumahku Sekolahku, kualitas manusia yang fitrah tidak segera disadari anak-anak. Setelah akal mereka berfungsi secara sempurna untuk berfikir, maka mulailah mengenali dan mencari jati dirinya.

Pada penerapan kearifan lokal yang dilakukan sekolah diharapkan peserta didik diberikan penyadaran akan lingkungannya, lalu diajak untuk mendalami bagaimana lingkungan tersebut membentuk karakter pada mereka, tentunya karakter yang positif. Bahkan anak diperintahkan untuk melepas uniformnya. Dengan demikian kesadaran untuk mematuhi tata tertib benar-benar dari kesadaran dirinya yang dalam. Hal ini sejalan dengan Undang-Undang Nomor 20 tahun 2003 tentang sistem pendidikan nasional ${ }^{14}$ yaitu "Pendidikan adalah usaha sadar terencana untuk mewujudkan suasana belajar dan proses pembelajaran agar peserta didik secara aktif mengembangkan potensi dirinya untuk memiliki kekuatan spiritual keagamaan, pengendalian diri, kepribadian, kecerdasan, akhlak mulia, serta keterampilan yang diperlukan darinya, masyarakat, bangsa, dan negara". Jelasnya menurut pendapat di atas bahwa dalam pembentukan karakter terutama pelaksanaan kearifan lokal sekolah bukan yang dikejar hanya pencintraan saja, tetapi lebih dari itu bahwa pembentukan nilai-nilai positif yang lahir dari kesadaran yang mendalam pada diri peserta didik yang diharapkan. Untuk menguatkan hal di atas menurut Doni Koesoema tantangan pendidikan karakter, diantaranya merupakan sebuah konsep atau gagasan yang sangat kompleks dan tidak bisa disederhanakan begitu saja.

Dari pernyataan tersebut tampak sekali kalau kearifan lokal sangat dibutuhkan dalam pembentukan karakter di sekolah karena dikhawatirkan akan ada kekuatan-kekuatan lain yang dapat mempengaruhi pembentukan karakter generasi muda. Kekuatan-kekuatan tersebut bisa jadi adalah budaya luar yang berbeda dengan budaya Indonesia yang religious. Apalagi di abad modern ini, dimana kekuatan luar itu memang sedang digandrung generasi muda, mereka lebih memilih dan tertarik dengan hal-hal baru yang berasal dari luar, seperti gaya hidup

${ }^{14}$ Undang-Undang Republik Indonesia Nomor 20 Tahun 2003, Sistem Pendidikan Nasional, Bandung: Citra Umbara, 2005, hal. 45. 
(lifestyle) para artis, musikus dunia mulai dari gaya pakian (fashion), rambut dan lain-lain. Bahkan Doni Koesoema menambahkan dalam bukunya "Pendidik Karakter di Zaman Keblinger", menyatakan berbicara tentang guru sebagai agen perubahan. $^{15}$

Berkaitan dengan kearifan lokal dalam pembahasan disertasi ini, maka penulis sedikit mengaitkan kebudayaan dalam perspektif Islam ini dengan kearifan lokal. Dimana kearifan lokal merupakan salah satu produk kebudayaan lokal. Sebagai produk kebudayaan, kearifan lokal lahir karena kebutuhan akan nilai, norma dan aturan yang menjadi model untuk (model for) melakukan suatu tindakan. Kearifan lokal juga merupakan salah satu sumber pengetahuan (kebudayaan) masyarakat, ada dalam tradisi dan sejarah, dalam pendidikan formal dan informal, seni, agama dan interpretasi kreatif lainnya.

\section{ISYARAT AL-QUR'AN TENTANG PENDIDIKAN KARAKTER BERBASIS AL-QUR'AN}

\begin{tabular}{|c|c|c|c|}
\hline NO & $\begin{array}{l}\text { NAMA } \\
\text { SURAT }\end{array}$ & AYAT & KONTEN AYAT \\
\hline 1 & $\begin{array}{l}\text { Surat Al- } \\
\text { Baqarah }\end{array}$ & 263 & $\begin{array}{l}\text { Pendidikan karakter berbasis } \\
\text { lingkungan (konservasi } \\
\text { lingkungan) }\end{array}$ \\
\hline 2 & $\begin{array}{l}\text { Surat Al- } \\
\text { Qalam }\end{array}$ & 4 & $\begin{array}{l}\text { Pendidikan karakter berbasis } \\
\text { potensi diri (konsevasi } \\
\text { humanis) }\end{array}$ \\
\hline 3 & $\begin{array}{l}\text { Surat Al- } \\
\text { Baqarah }\end{array}$ & 228 & $\begin{array}{l}\text { Pendidikan karakter berbasis } \\
\text { nilai budaya (konservasi } \\
\text { budaya) }\end{array}$ \\
\hline 4 & An-Nisa & 104 & $\begin{array}{l}\text { Pendidikan karakter berbasis } \\
\text { nilai budaya (konsevasi budaya) }\end{array}$ \\
\hline 5 & Luqman & $\begin{array}{c}12,13 \\
14\end{array}$ & $\begin{array}{l}\text { Pendidikan karakter berbasis } \\
\text { nilai religious (konservasi } \\
\text { moral) }\end{array}$ \\
\hline 6 & An-Nisa & 9 & $\begin{array}{l}\text { Pendidikan karakter berbasis } \\
\text { nilai religious, (konservasi } \\
\text { moral) }\end{array}$ \\
\hline 7 & Surat Al-A'raf & 189 & $\begin{array}{l}\text { Pendidikan kearifan lokal } \\
\text { berbasis nilai budaya } \\
\text { (konservasi budaya) }\end{array}$ \\
\hline
\end{tabular}

${ }^{15}$ Doni Koesoema A., Pendidik Karakter di Zaman Keblinger, Jakarta: Grasindo, 2007, hal. 116. 
Konsep Pendidikan Kearifan Lokal Nilai Kesundaan dalam Sistem Satuan Pendidikan Berbasis Al-Qur'an.

\begin{tabular}{|c|c|c|c|}
\hline No & Nama Hari & Tema Hari & Rujukan dalam Al-Qur'an \\
\hline 1 & Senin & $\begin{array}{l}\text { Ajeg } \\
\text { Nusantara }\end{array}$ & $\begin{array}{l}\text { Al-Qashash/28:85; } \\
\text { Al-Hasyr/59:8-9; } \\
\text { At-Taubah/9:24,122; } \\
\text { An-Nisa'/4:66; } \\
\text { Al-Baqarah/2:126; }\end{array}$ \\
\hline 2 & Selasa & $\begin{array}{l}\text { Mapag } \\
\text { Buana }\end{array}$ & $\begin{array}{l}\text { Al-Hujarat/49:13; } \\
\text { Ar-Ruum/30:22; } \\
\text { Al-Baqarah/2:201; } \\
\text { Al-Qashah/28:77; }\end{array}$ \\
\hline 3 & Rabo & $\begin{array}{l}\text { Maneuh di } \\
\text { Sunda }\end{array}$ & $\begin{array}{l}\text { Al-A'raaf/7:199. } \\
\text { An-Nahl/16:123; }\end{array}$ \\
\hline 4 & Kamis & $\begin{array}{l}\text { Nyanding } \\
\text { Wawangi }\end{array}$ & $\begin{array}{l}\text { Qaf/50: } 6 \\
\text { Al-Maaidah/5:4 } \\
\text { An-Nahl/16:5-6 } \\
\text { Al-A'raf/7:26 } \\
\text { Al-Insaan/76:21; }\end{array}$ \\
\hline 5 & Jum'at & $\begin{array}{l}\text { Nyucikeun } \\
\text { Diri }\end{array}$ & $\begin{array}{l}\text { Al-Baqarah/2:222; } \\
\text { An-Nur/24:31; } \\
\text { Al-Hujurat/49:11; } \\
\text { As-Syams/91:9; } \\
\text { Al-A'laa/87:14; } \\
\text { Ar-Ra'ad/13:28; } \\
\text { Al-Fajri/89:27; } \\
\text { Ali Imran/3:159. }\end{array}$ \\
\hline 6 & Sabtu & $\begin{array}{l}\text { Betah di } \\
\text { Imah }\end{array}$ & $\begin{array}{l}\text { Al-Isra'/17:23-24; } \\
\text { Luqman/31:14-15; } \\
\text { Al-Baqarah/2:215; }\end{array}$ \\
\hline 7 & Minggu & & $\begin{array}{l}\text { Al-Ankabut/29:8; } \\
\text { Al-Ahqaf/46:15-17; }\end{array}$ \\
\hline
\end{tabular}


Penguatan Pendidikan Karakter Melalui Kearifan Lokal Berbasis Al-Qur'an |

\section{PENDIDIKAN KARAKTER MELALUI KEARIFAN LOKAL DI SMA NEGERI KABUPATEN PURWAKARTA}

Secara umum, budaya lokal atau budaya daerah dimaknai sebagai budaya yang berkembang di suatu daerah yang unsurunsurnya adalah budaya suku bangsa yang tinggal di daerah itu. Pemaknaan terhadap kearifan lokal dalam dunia pendidikan pun tampaknya masih sangat kurang. Ada istilah muatan lokal dalam struktur kurikulum pendidikan, tetapi pemaknaannya sangat formal karena muatan lokal kurang mengeksporasi kearifan lokal. Muatan lokal hanya sebatas bahasa daerah dan tari daerah yang diajarkan kepada siswa.

Tantangan dunia pendidikan ini sangatlah kompleks, apalagi jika dikaitkan dengan kemajuan global di bidang sains dan teknologi, nilai-nilai lokal mulai memudar dan ditinggalkan. Karena itu eksplorasi terhadap kekayaan luhur budaya bangsa sangat perlu dilakukan. Padahal pendidikan kearifan lokal sangat berfungsi untuk mendasari perkembangan dan pertumbuhan selanjutnya sekaligus pribadi yang tidak terprovokasi yakni pribadi yang welas asih, wicaksono, sigsaya, andap asor dan ajur ajer. ${ }^{16}$ Kata-kata sikap yang dilukiskan itu adalah kata-kata yang terdapat pada kearifan lokal masyarakat jawa.

Kearifan lokal yang terangkum dalam pendidikan karakter ini memiliki enam prinsip, yaitu: Pertama, pendidikan karakter bukan sebuah subjek tetapi bagian dari kehidupan akademik dan sosial siswa. Kedua, pendidikan karakter terintegrasi adalah pendidikan tindakan. Ketiga, Lingkungan sekolah yang positif membantu membangun karakter. Keempat, Pengembangan karakter didorong melalui kebijakan administrasi dan latihan. Kelima, Para pendidik yang dikuasakan untuk mempromosikan pengembangan karakter. Keenam, Sekolah dan masyarakat adalah mitra penting dalam pengembangan karakter. ${ }^{17}$ Keenam pola pendidikan karakter tersebut menjadi sebuah gerakan nasional untuk menciptakan sekolah yang membina generasi muda beretika, bertanggung jawab, dan peduli melalui pemodelan dan mengajarkan karakter dengan penekanan nilai universal yang kita

\footnotetext{
${ }^{16}$ Tukiran dan Daun dalam Ratna Megawangi, 2003. Pendidikan Karakter untuk Membangun Masyarakat Madani, IPPK-Indonesia Heritage Foundation, hal. 38 .

${ }^{17}$ Timothy Rusnak, The Six Principles of Integrated Character Education, dalam An Integrated Approach to Character Education, California: Corwin Press Inc, 1998, hal. 7.
} 
setujui bersama. Ini adalah suatu usaha yang disengaja dan proaktif baik dari sekolah, daerah, dan juga negara untuk menanamkan siswanya pada nilai etika utama seperti menghargai diri sendiri dan orang lain, bertanggung jawab, integritas, dan disiplin diri. Ini bukanlah suatu "perbaikan cepat" atau "obat kilat untuk semua". Pendidikan karakter boleh ditujukan pada keprihatinan kritis seperti siswa, pada kemungkinan yang terbaik, pendidikan karakter mengintegrasikan nilai positif ke setiap aspek dari hari-hari di sekolah.

\section{E. MODEL PENGUATAN PENDIDIKAN KARAKTER DI SMA NEGERI KABUPATEN PURWAKARTA}

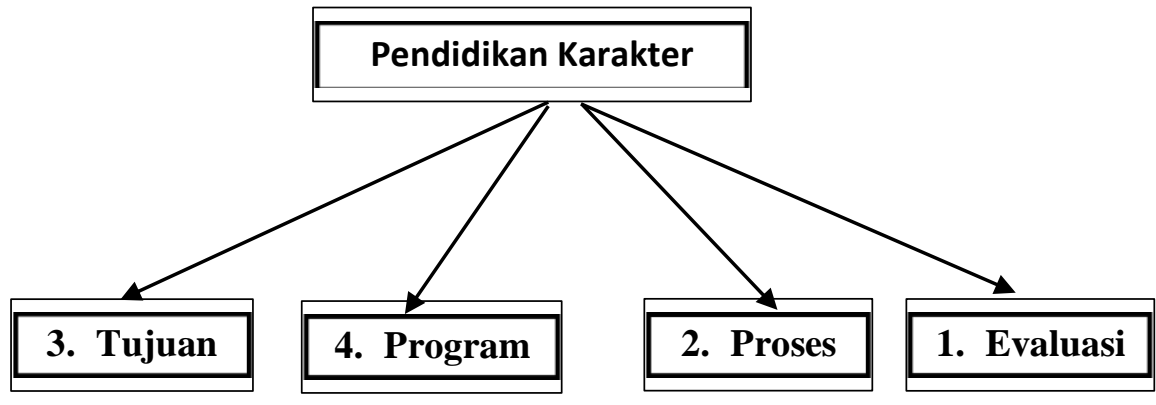

Penjelasan dari ganbar di atas adalah bahwa Tujuan merupakan kristalisasi nilai-nilai yang berfungsi mengarahkan, sekaligus memberi makna pada program dan proses berikutnya. Nilai yang terkandung dalam tujuan pendidikan karakter berdimensi keIslaman, kelndonesiaan serta tujuan praktis pembelajaran ini menjadi tujuan pendidikan karakter yang akan berfungsi sebagai pedoman dalam menentukan ruang lingkup pendidikan dan dinamikanya.

Program merupakan rancangan yang terencana dan terukur yang dimaksudkan untuk dapat mencapai tujuan pendidikan yang sudah ditentukan. Program akan menentukan kualitas ketercapaian pendidikan. Kalau programnya tepat sesuai dengan tujuan, maka program itu bisa dijalankan dengan baik pula.

Proses dalam pendidikan memiliki makna yang strategis, karena tujuan dan program yang baik belum tentu baik kalau prosesnya tidak tepat. proses adalah suatu kegiatan yang mengarahkan dengan sengaja program yang telah dirancang untuk mencapai tujuan yang hendak dicapai. 
Evaluasi sangat penting dalam proses pendidikan, karena tujuan evaluasi pendidikan bukan hanya untuk mengukur keberhasilan program pendidikan, tetapi juga sebagai langkah korektif untuk terus memperbaiki dan mengembangkan pendidikan ke arah yang lebih baik. Hasil evaluasi dapat jugs digunakan oleh guru-guru dan pengawas pendidikan untuk menilai keefektifan pengalaman pembelajaran, kegiatan-kegiatan belajar, dan metode-metode pembelajaran yang digunakan.

Setiap komponen dalam kerangka model ini dikembangkan lagi dalam sub-sub komponen, untuk lebih jelasnya dapat dilihat dalam gambar di bawah ini:

\section{Gambar: 3}

\section{Komponen Model Pendidikan Karakter}

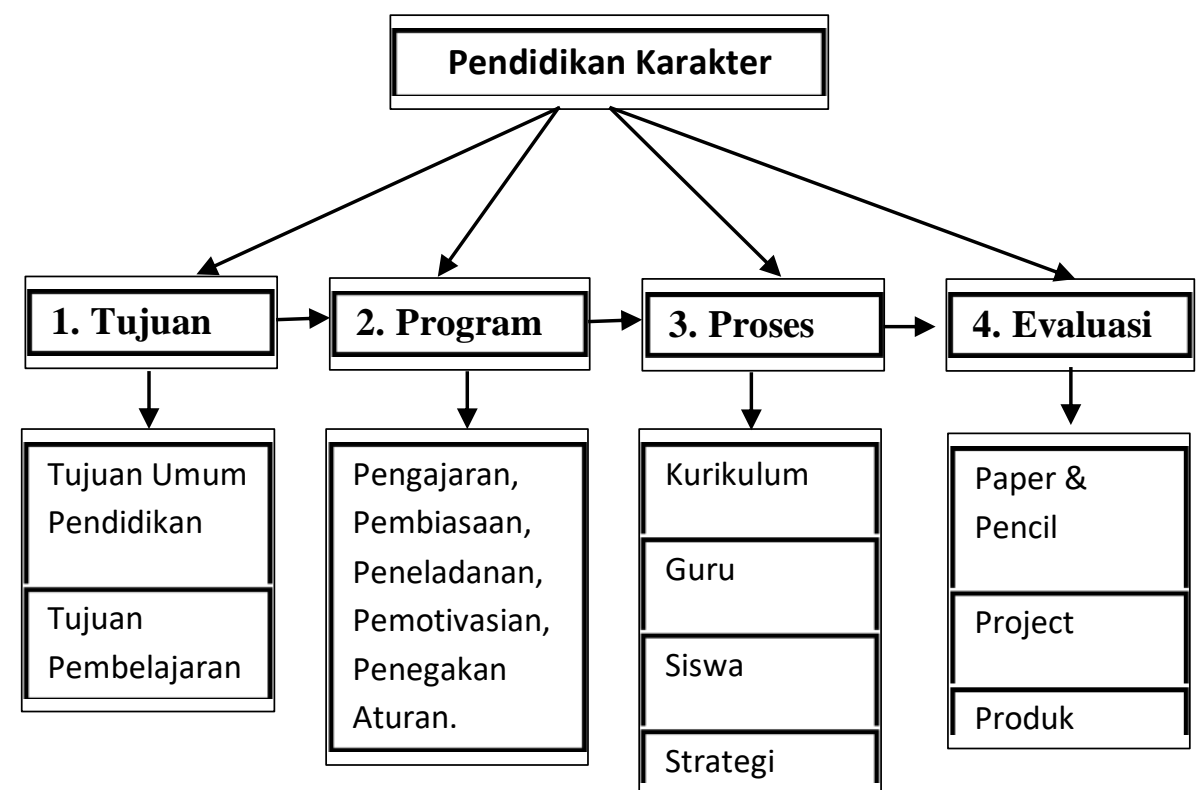

\section{F. PENUTUP}

Setelah menguraikan pembahasan dan analisis terhadap judul yang dikaji dalam hasil penelitian ini, maka dapat dikemukakan beberapa kesimpulan berikut:Pertama, Bagaimana Konsep dan Paradigma Pendidikan Karakter. Pendidikan karakter adalah sebuah gerakan nasional untuk menciptakan sekolah yang membina generasi muda beretika, bertanggung jawab, dan peduli melalui pemodelan dan mengajarkan karakter dengan penekanan nilai universal yang kita setujui bersama. Kedua, bagaimana implementasi penguatan pendidikan Karakter melalui kearifan 
local berbasis Al-Qur'an pada SMAN Kabupaten Purwakarta ini. Untuk mendeskripsikan pendidikan kearifan lokal berbasis Al-Qur'an pada SMAN Kecamatan Purwakarta ini dimulai dengan pembentukan karakter manusia yang diawali dari fitrah Ilahi kemudian membentuk jati diri dan perilaku. Oleh karena itu, sekolah sebagai bagian dari lingkungan memiliki peranan penting dalam pembentukan karakter diri.

Implikasi dari penguatan pendidikan karakter melalui kearifan lokal berbasis Al-Qur'an Pada SMA Negeri di Kabupaten Purwakarta ini dapat dilihat dari adanya pemahaman konsep dari pendidikan sebagai pembangunan karakter anak bangsa yang selanjutnya dijadikan acuan dalam bentuk kegiatan pendidikan kearifan lokal yang memanfaatkan, mengelola, dan melestarikan tradisi atau budaya sekolah pada setiap jenjang pendidikan dasar hingga menengah di Kabupaten Purwakarta. Hal ini pula yang melatarbelakangi keluarnya Peraturan Bupati Purwakarta Nomor 69 Tahun 2015 tentang "Pendidikan Berkarakter" dengan mengusung semangat "Revolusi Mental". Sebuah program gerakan prestasi kebudayaan bidang pendidikan berkarakter yang berpijak pada kearifan lokal, dikenal dengan program "Atikan Tujuh Poe Istimewa". Program ini selanjutnya disosialisasikan sebagai pendidikan kearifan lokal pada semua jenjang pendidikan formal di Kabupaten Purwakarta dengan tujuan untuk melahirkan generasi yang istimewa.

\section{DAFTAR PUSTAKA}

'Aziz, Shalih Abdul, At-Tarbiyah Thuru at-Tadris, Mesir: Dar Al-Ma'rif, 2000.

'Ulwan, Abdullah, Tarbiyatul Aulad fil lslam. Jilid I \& II. Beirut: Darus Salam, 1978.

Abdullah, Abdurrahman Shalih, Educational Theor, Qur'anic Outlook, Mekkah Arab Saudi, Umm al-Quran University, 1982.

Abdullah, Amin, Dinamika Islam Kultural, Bandung: Mizan, 2000 . 
Penguatan Pendidikan Karakter Melalui Kearifan Lokal Berbasis Al-Qur'an |

Abdullah, Irwan, dkk., Agama dan Kearifan Lokal dalam Tantangan Global, Yogyakarta: Pustaka Pelajar, 2008.

Abdurrahman bin Muhammad bin Khaldun, Mukaddimah Ibnu Khaldun, (Terj.) Masturi Irham, Jakarta: Pustaka alKautsar, 2001.

Abdurrahman, Dudung et.al, Sejarah Peradaban Islam Dari Masa Klasik Hingga Modern, Yogyakarta: Fak. Adab, 2002.

Agustian, Ary Ginanjar, Rahasia Sukses Membangun Kecerdasan Emosi dan Spiritual ESQ, Jakarta: Arga, 2001.

Ahmed, Munir-ud-Din, Muslim Education and The Scolar's Social Status: Up to The 5th Century Muslim Era (11th Century Christian Era) in The Light of Ta 'rikh Baghdad, Verlag Der Islam, Zurich, 1969.

Al Munawar, Said Agil Husin, Al-Qur'an Membangun Tradisi Kesalehan Hakiki, Abdul Halim (ed.), Jakarta: Ciputat Press, 2002.

Al Maraghi, Ahmad Musthafa, Tafsir Al-Maraghi, Beirut Lubnan, Dar el Fikr, 2001.

-------, Aktualisasi Nilai-Nilai Qur'ani dalam Sistem Pendidikan Islam, Ciputat: Ciputat Press, 2005.

Al-Abrasyi, Muhammad 'Athiyah, Dasar-Dasar Pokok Pendidikan Islam, terj. Bustami A. Gani dan Djohar Bahry , Jakarta: Bulan Bintang, 2014.

Al-Attas, Syed Muhammad an-Naquib, Konsep Pendidikan dalam Islam, terj. Haidar Bagir, Bandung: Mizan, 2004.

Al-Bani, Muhammad Nasiruddin, Silsilah al-Hadits Do'ifah, Riyadh: al-Ma'arif, 2000.

Al-Biladi, Atiq bin Ghaits, Keutamaan Kota Mekah, Bandung: Pustaka Hidayah, 1995. 